REPORTS OF MORPHOLOGY
Official Journal of the Scientific Society of Anatomists,
Histologists, Embryologists and Topographic Anatomists
of Ukraine
journal homepage: https://morphology-journal.com

\title{
Determination of individual teleroentgenographic characteristics of the lower medial incisors position in Ukrainian young men and young women with orthognathic bite
}

\author{
Dmitriev M.O.', Gunas I.V. ${ }^{1}$, Dzevulska I.V. ${ }^{2}$, Glushak A.A. ${ }^{1}$ \\ ${ }^{1}$ National Pirogov Memorial Medical University, Vinnytsya, Ukraine
} ${ }^{2}$ Bogomolets National Medical University, Kyiv, Ukraine

\section{ARTICLE INFO}

Received: 09 July, 2018

Accepted: 15 August, 2018

UDC: $616.716 .8-071-084: 613.956:$

617.52: $616.34 .25-007.481-7$

\section{CORRESPONDING AUTHOR}

e-mail: dmitriyevnik@gmail.com Dmitriev M.O.

\begin{abstract}
Ethnic, sexual and age features of the incisors positions point to the need for the development of techniques that allow to determine their individual characteristics, since commonly accepted standards recommended for optimal positioning of incisors can only be used as indicative. The purpose of the study - by studying teleroentgenographic indices and conducting direct stepwise regression analysis in young men and young women of Ukraine with orthognathic bite, to develop and analyze the mathematical models of individual characteristics of the position of the lower medial incisors. With the Veraviewepocs 3D device, Morita (Japan) in 38 young men (17 to 21 years of age) and 55 young women (aged from 16 to 20 years) with occlusion close to orthognathic bite and balanced faces received side teleroentgenograms. Cephalometric analysis was performed using OnyxCeph ${ }^{3 \mathrm{TM}}$ software. Cephalometric points and measurements were performed according to the recommendations of A.M. Schwarz, J. McNamara, W.B. Downs, R.A. Holdway, P.F. Schmuth, C.C. Steiner and C.H. Tweed. According to the above methods, in the licensed package "Statistica 6.0" using direct straight line regression analysis, the teleroentgenographic characteristics of the position of the lower medial incisors (distance 1I_NB, distance 1I_APog, angle 1I_DOP, IMPA angle, Mand1_NB angle, FMIA angle and Mand1_Melm angle) were performed. In young men with orthognathic bite of 7 possible models of teleroentgenographic characteristics of the lower medial incisors, 5 were constructed with determination coefficient $R^{2}$ from 0.694 to 0.849 , and in young women, all 7 possible models with determination coefficient $R^{2}$ from 0.595 to 0.794 . In young men most often the regression equations included - the angle ANB and facial vertical index GL_SN_S (by 11.5\%); lower face height ANS_ME, face angle NBA_PTGN and distance $S \_-\bar{E}$ (by 7.7\%). In young women most often the regression equations included - the angle of N_POG (16.7\%); Wits indicator (13.9\%); inclination angle I (8.3\%); $\mathrm{H}$-angle, maxillo-mandibular angle MM and angle of facial axis NBA_PTGN (by 5.6\%). Thus, in the work with the help of the method of stepwise regression with inclusion, among Ukrainians of juvenileage, on the basis of features teleroentgenographic indicators, the analysis of reliable models of individual teleroentgenographic characteristics of the position of the lower medial incisors was developed and carried out.

Keywords: lower medial incisors position, teleroentgenographic, regression analysis, orthognathic bite, young men, young women.
\end{abstract}

\section{Introduction}

Determination of the position of the lower incisors in the sagittal plane is one of the key positions in the diagnosis, planning and control of treatment of dental ankles [9, 25]. First of all, because together with the upper incisors, in addition to the function of biting, they also play an aesthetic function. Their position provides the formation of a soft profile of the lower third of the face. The position of the incisors in the sagittal plane (inclination), the position of the lips and the chin morphology play a key role in the evaluation and perception of the results of orthodontic treatment from the position of aesthetics, both doctors and patients themselves [16]. 
To objectivize the determination of the position of the lower incisors, the researchers studied the location of the central axes and the position of the cutting edge and the vestibular (lip) surface to different cephalometric planes [8, $24,26-28,30]$. But the use of unified standards is criticized by many researchers, proving the variability of these indicators. So E. Hernandez-Sayago et al. [14] determined the presence of a statistically significant difference in the inclination of the lower incisors in relation to the length of the anterior base of the skull, the angle of McHorris, the closure and mandibular planes, and offer a differentiated approach that determines the inclination of incisors, depending on the nature of the bite and the face type.

R. MoraHurtado, M.E. VeraSerna and E. Uribe-Querol [25] point to the importance of choosing an orthodontic device that affects the position of the lower incisors, depending on the type of patient's face. Namely, their study in individuals with normognatic type of closure of molars (class 1 by Engle) revealed statistically significant differences in the characteristics of the lower incisors between the mesocephalic and brachiocephalic types and the increase in the inclusions of the latter in dolichocephalic compared with brachycephalic.

A number of studies have found that the position of the lower incisors is not only closely related to the morphology of the chin symphysis and the direction of face growth [23], but also with the features of the closing plane itself [20], as well as the position of the lower incisors affects the nature of the closure and the nature of the movement of the dentition relative to each other [10]. Moreover, M.M. Alabdullah et al. [1] found a direct linear relationship between the force of chewing muscles and the angular characteristics of the incisors.

In addition to its aesthetic and functional significance, the literature constantly poses questions about the influence of the position of the lower incisors on the state of periodontal tissues, that is, the structures that hold and allow the tooth function to function properly. It is the emergence of a gum recession and is the most undesirable and potentially dangerous complication in the orthodontic displacement of incisors, which is indicated by the study of D. Ciavarella et al. [2], D.T. Garlock et al. [11], M. Tepedino et al. [29].

The purpose of the study - by studying teleroentgenographic indices and conducting direct stepwise regression analysis in young men and women of Ukraine with orthognathic bite, to develop and analyze the mathematical models of individual characteristics of the position of the lower medial incisors.

\section{Materials and methods}

With the Veraviewepocs 3D device, Morita (Japan) in 38 young men (17 to 21 years of age) and 55 young women (aged from 16 to 20 years) with occlusion close to orthognathic bite and balanced faces received side teleroentgenograms. Cephalometric analysis was performed using OnyxCeph ${ }^{3 \mathrm{TM}}$ software. Cephalometric

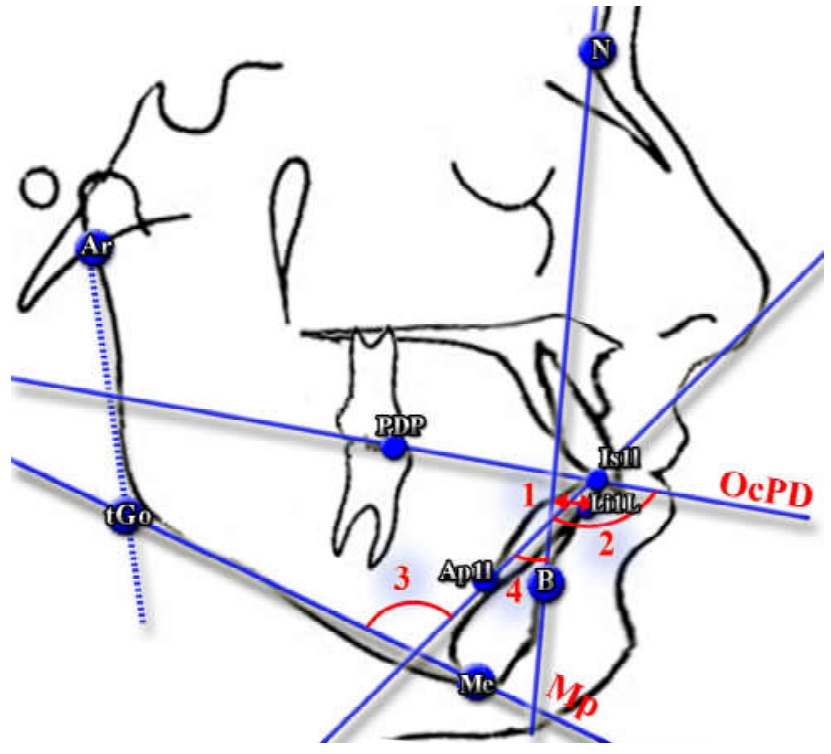

Fig. 1. Teleroentgenographic characteristics position of the lower medial incisors. 1-NB_1I(distance 1I_NB), distance from the point $\underline{\mathrm{Li} 1 \mathrm{~L}}$ to the line $\mathrm{N}-\mathrm{B}$ (determines the anterior-posterior location of the crown part of the lower medial incisor to the line N-B); 2 DOP_1I (angle 1I_DOP), formed by the Ap1L-Is1L (center axis of the lower medial incisor) and ADP-PDP lines (occlusion plane by Downs, OcPD), measure of deviation from a straight angle with a positive value in the clockwise direction, with a negative against the course of the latter; 3 - IMPA (IMPA angle, Incisor Mandibular Plane Angle) - is formed by lines Ap1L-Is1L (center axis of the lower medial incisor) and tGo-Me (mandibular plane $\mathrm{Mp}$ ) (characterizes the inclination of the lower medial incisor to the mandibular plane). By Downs method, this indicator for convenience and more clinical practicality is used at a reduced size of $90^{\circ}$ and can take both negative and positive values, and is called MEGO_1L; in Schwarz method this figure is called MAND1_ML (angle Mand1_ML); 4-MAND1_NB (angle Mand1_NB), formed by lines Ap1L-Is $\overline{1} \mathrm{~L}$ (tilt central axis of the lower medial incisor) and $\underline{\mathrm{N}-\mathrm{B}}$.

points and measurements were performed according to the recommendations of A.M. Schwarz [27], J. McNamara [24], W.B. Downs [8], R.A. Holdway [15], P.F. Schmuth [26], C.C. Steiner [28] and C.H. Tweed [30]. The analysis of teleroentgenograms and the results of their researches for Ukrainian young men and young women is described in detail and set out in a number of articles [4-7, 12, 13].

We, in accordance with the above-mentioned methods, simulated the teleroentgenographic characteristics of the position of the lower medial incisors (Fig. 1, 2).

The statistical processing of the obtained results was carried out in the license package "Statistica 6.0" using a direct stepwise regression analysis.

\section{Results}

As a result of modeling teleroentgenographic characteristics of the position of the lower medial incisors in young men and women with orthognathic bite, depending on the metric parameters of the skull, we have constructed linear equations for the following indices. 


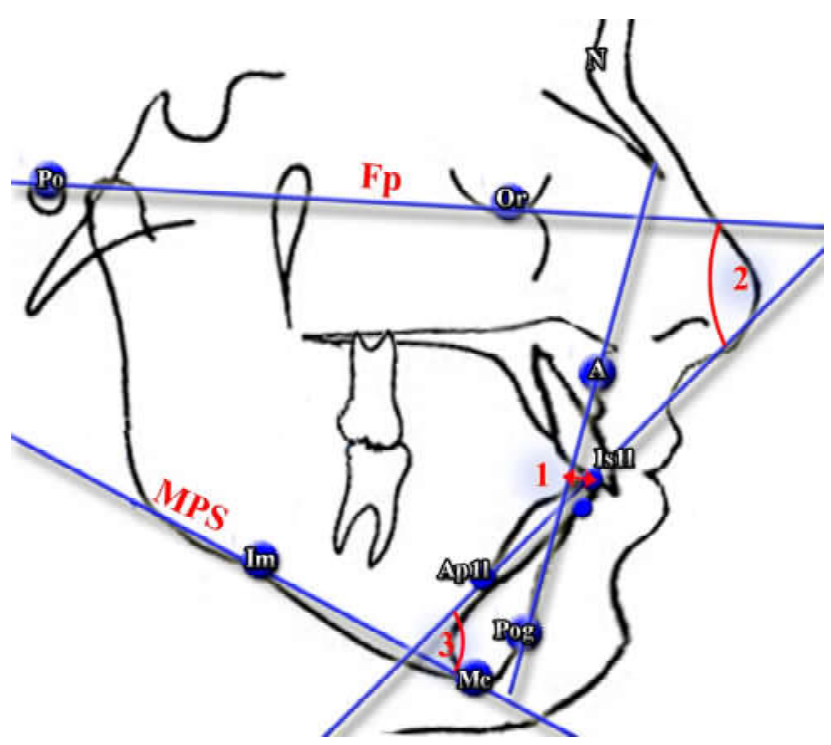

Fig. 2. Teleroentgenographic characteristics position of the lower medial incisors. 1 - APOG_1L (distance 1I_APog) - the distance from the point Is $1 \mathrm{~L}$ to the line A-Pog (if the distance is medial, that is, the cutting edge of the incisor is in the front with respect to the line position, then the indicator takes a positive value, and if the distance is distal, that is the cutting edge of the incisor is in the posterior with respect to the line position, then the indicator takes a negative value); 2 - FMIA (angle FMIA, Frankfort Mandibular Incisor Angle), formed by the lines Is1L-Ap1L (center axis of the lower medial incisor) and $\mathrm{Po}$-Or (Frankfurter plane, $\mathrm{Fp}$ ) (angle of inclination of the lower median incisor to the Frankfurter plane, Fp); 3 - MAND1_ME (angle Mand1_Melm) - is formed by lines Ap1L-Is1L (inclination of the central axis of the lower medial incisor) and Im-Me (mandibular plane by Schwarz, MPS).

For young men:

FMIA $=153.1-1.931 \times A N B+0.714 \times$ PN_POG $-0.829 x$ NBA_PTGN - $0.362 \times$ S_E $\left(R^{2}=0.804 ; F_{(4.31)}=31.87 ; p<0.001\right.$; Error of estimate $=3.263)$;

IMPA = 108.2 - 0.518 $\times$ ARGOME + $0.828 \times$ WITS + 0.893 $x$ S_E + $0.316 \times \mathrm{F}+0.564 \times$ N_POG_+ $0.213 \times$ AFH_PFH $0.181 \times$ GL_SN_S $\left(R^{2}=0.848 ; F_{(7.28)}=22.31 ; p<0.001\right.$; Error of estimate $=3.462$ );

MAND1_ME $=175.2+0.989 \times \mathrm{B}-1.271 \times \mathrm{MM}-0.546 \mathrm{x}$ MAND + $0.243 \times$ GL_SN_S + $0.424 \times$ ANS_ME $\left(R^{2}=0.849\right.$; $F_{(5.30)}=33.67 ; p<0.001 ;$ Error of estimate $\left.=3.351\right)$;

MAND1_NB $=30.38+1.872 \times$ ANB $-0.221 \times$ GL_SN_S + $0.463 \times$ COND_A- $0.424 \times$ ANS_ME $\left(R^{2}=0.694 ; F_{(4.31)}=17.58\right.$; $\mathrm{p}<0.001$; Error of estimate $=3.295)$;

NB_1L $=10.56+0.792 \times$ ANB $-0.049 \times$ N_SP_SP $0.350 \times$ MAX $+0.136 \times$ NBA_PTGN $+0.122 \times$ N_SE -0.082 $\times \mathrm{H} \quad\left(\mathrm{R}^{2}=0.729 ; \quad \mathrm{F}_{(6.30)}=13.44 ; \mathrm{p}<0.001 ;\right.$ Error of estimate $=0.798$ ).

For young women:

APOG_1L $=-21.09+0.349 \times$ N_POG_ $+0.279 \times$ AFH $0.144 \times$ GL_SNPOG $-0.242 \times$ S_L + $0.342 \times$ NBA_PTGN $0.122 \times$ NSBA $\left(R^{2}=0.614 ; F_{(6.47)}=12.48 ; p<0.001\right.$; Error of estimate=1.222);

DOP_1L $=95.29+1.822 \times$ WITS $+0.838 \times$ N_POG_+ $0.716 \times \bar{M} A X \_M A N D-0.964 \times$ SND $-0.396 \times$ POR_GNS
$\left(R^{2}=0.641 ; F_{(6.47)}=14.00 ; p<0.001 ;\right.$ Error of estimate=4.011);

FMIA $=98.34-0.351 \times$ MM $-0.279 \times$ N_POG_ $+0.775 x$ PN_POG - $0.986 \times$ WITS $-0.815 \times$ PN_A $\left(R^{2}=0.794\right.$; $F_{(5.45)}=34.62 ; p<0.001$; Error of estimate $\left.=3.652\right)$;

IMPA $=-48.78+1.484 \times$ WITS $+0.599 \times$ NAPOG +1.390 xI-0.565 xP_OR_N + 1.010 xH-0.727 x ML_NL $\left(R^{2}=0.771\right.$; $F_{(6.44)}=24.76 ; \bar{p}<0.001$; Error of estimate $\left.=3.658\right)$;

MAND1_ME $=144.2-1.677 \times$ WITS + $0.456 \times$ FMA $0.395 \times \mathrm{MM}-0.500 \times \mathrm{N} \_P O G \_-0.326 \times \mathrm{I}\left(\mathrm{R}^{2}=0.742 \text {; }\right.$ $F_{(5.45)}=25.90 ; p<0.001$; Error of estimate=3.679);

MAND1_NB $=-76.80+0.597 \times$ NAPOG $+1.085 \times$ WITS + $0.669 \times \mathrm{I}+0.504 \times \mathrm{H}+0.362 \times \mathrm{N}$ POG_- $0.333 \times \mathrm{S} \_\mathrm{E}$ $\left(R^{2}=0.736 ; F_{(6.44)}=20.50 ; p<0.001 ;\right.$ Error of estimate=3.608);

NB_1L $=-7.468+0.183 \times$ N_POG_ $+0.157 \times$ ANS_ME + $0.163 \times A \_N \_P O\left(R^{2}=0.595 ; F_{(3.50)}=24.47 ; p<0.001\right.$; Error of estimate $=1.097$ ).

In these models:

$\mathrm{R}^{2}$ - coefficient of determination;

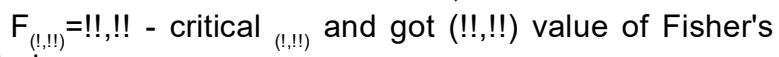
criterion;

St. Error of estimate - standard error of the standardized regression coefficient;

A_N_Po (distance A_N_Pog) - distance from the point A to the line $\mathrm{N}$-Pog (the face plane, characterizes the degree of convexity of the face);

$\mathrm{AFH}$ (distance AFH or front height of the face) - distance from the point Me to the line ANS-PNS;

AFH_PFH (ratio AFH_PFH) - distance ratio from the point

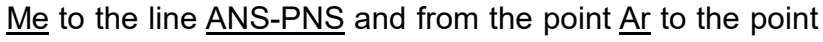
$\underline{\mathrm{tGo}}$ (the ratio between the front $(\mathrm{AFH})$ and rear $(\mathrm{PFH})$ face height);

ANB (angle ANB) - is formed by lines $\underline{A-N}$ and $\underline{N-B}$ (indicates an angular interstitial relation in the anteriorposterior direction; angle ANB is considered positive if point $\underline{A}$ is in front of $\underline{N B}$; if the lines $\underline{N A}$ and $\underline{N B}$ overlap, then the ANB angle is $0^{\circ}$; if point $\underline{A}$ is behind the $\underline{N B}$ line, then the angle is considered negative);

ANS_ME (lower face height) - distance from the point ANS to the point Me;

ARGOME (angle Ar-Go-Me, or the angle of the mandible) - is formed by lines Ar-tGo and tGo-Me;

B (basal angle) - formed by lines ANS-PNS (palatine plane $\underline{\mathrm{SpP}}$ ) and Im-Me (mandibular plane MPS by Schwarz) (indicates the angle between the upper and lower jaws);

COND_A (effective length of the upper jaw) - distance from the point $\underline{\text { Cond }}$ to the point $\underline{A}$;

$\mathrm{F}$ (face angle or angle $\mathrm{F}$ ) - formed by lines $\underline{\mathrm{Se}-\mathrm{N}}$ and $\underline{\mathrm{N}}$ A (determines the location of the anterior contour of the upper jaw in the jet plane to the base of the skull);

FMA (POr_MeGo) (angle FMA, Frankfort Mandibular Angle) - formed by lines tGo-Me (mandibular plane $\underline{\mathrm{Mp}}$ ) and Po-Or (Frankfurt plane Fp);

GL_SN_S (index Gl'_Sn_Sn_Gn' or facial vertical index)

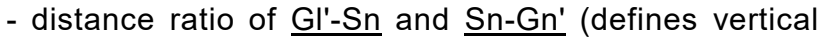
relationships in the face profile);

GL_SNPOG (angle Gl'SnPog' or indicator of convexity 
of the soft tissue profile) - formed by lines $\underline{\mathrm{Gl}}-\mathrm{Sn}$ and $\underline{\mathrm{Sn}}$ Pog';

$\mathrm{H}$ (H-angle) - formed by lines Po-Or (Frankfurt plane $\underline{F p}$ ) and $\underline{P n}$ (nasal perpendicular, perpendicular to the line from the point $\underline{N^{\prime}}$ to the line $\underline{\text { Se-N}}$ ), defines the angle of the inclination of the Frankfurt plane to the base of the skull;

I (angle I, inclination angle) - angle formed by line ANS$\underline{\mathrm{PNS}}$ and $\underline{\mathrm{Pn}}$ (nasal perpendicular, perpendicular to the line from the point $\underline{N}$ ' to the line $\underline{\text { Se-N}}$ ), angle of inclination of the upper jaw (spinal plane) to the nasal perpendicular;

MAND (length of the lower jaw) - distance from the constructive point $\underline{\mathrm{tGoS}}$ to the constructive point apMandS;

MAX (length of the upper jaw) - distance from the constructive point apMax to the point PNS;

MAX_MAND (maxillo-mandibular difference) - difference between distances Cond-A and Cond-Gn;

ML_NL (SpP_GoMe, base angle) - formed by lines ANS$\underline{\mathrm{PNS}}$ and tGo-Me (the angle between the palatal SpP and the mandibular MP planes);

MM (maxillo-mandibular angle) - is formed by lines $\underline{A-B}$ and ANS-PNS (defines the angle below which the upper jaw is located in relation to the lower jaw in the jet plane);

N_POG_ (angle N'Hold_Pog'_Hline) - angle between lines Ls-Pog' ( $\underline{\mathrm{H} \text { line }}, \mathrm{Holdway}$ line) and N'Hold-Pog';

N_SE (distance Se_N or the length of the front of the skull base by Steiner) - distance from the point $\underline{\text { Se }}$ to the point $\underline{\mathrm{N}}$;

N_SP_SP (coefficient N_Sp'_Sp'_Me) - distance ratio $\underline{\mathrm{N}-\mathrm{Sp}}$ ' and $\underline{\mathrm{Sp}}$-Me (the ratio of the upper and lower height of the face);

NAPOG (angle of the skeletal face obliquity, or angle NaPog) - formed by lines $\mathrm{N}-\mathrm{A}$ and $\mathrm{A}$-Pog;

NBA_PTGN (angle NBa-PtGn or the angle of the front axle) - formed by lines $\underline{\mathrm{N}-\mathrm{Ba}}$ and $\mathrm{Pt}-\mathrm{Gn}$ (determines the direction of development of the mandible);

NSBA (angle NSBA) - formed by lines $\underline{\mathrm{S}-\mathrm{N}}$ (the front part of the skull base) and $\underline{\mathrm{S}-\mathrm{Ba}}$;

P_OR_N (soft tissue angle, or angle

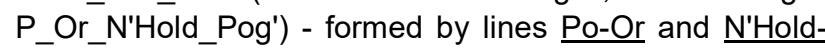
Pog';

PN_A (distance PN_A) - distance from the point A to the point $\underline{P N m}$ (perpendicular line from the point $\underline{N}$ to the line Po-Or). If the point $A$ is distal from the nasal perpendicular, then the indicator takes a negative value, and if the medial than a positive value;

PN_POG (distance PN_Pog) - distance from the point $\underline{P o g}$ to the nose perpendicular $\underline{P N}$ (perpendicular line from the point $\underline{N}$ to the line $\mathrm{Po-Or}$ );

POR_GNS (Y-axis or angle POr_GnS) - angle formed by lines $\underline{\mathrm{P}_{\mathrm{o}}-\mathrm{Or}}$ and $\underline{\mathrm{S}-\mathrm{Gn}}$ (angle of inclination $\mathrm{Y}$-axis relative to the Frankfurt horizontal);

S_E (distance S_E or the length of the back of the skull base by Steiner) - distance from the point $\underline{S}$ to a constructive point E, which is located at an intersection of the perpendicular carried out from the point ppCond to the line $\underline{\mathrm{S}-\mathrm{N}}$
S_L (distance S_L or the front length of the skull base by Steiner) - from the point $\underline{S}$ to a constructive point $\underline{L}$, which is formed at the intersection of the perpendicular carried out from the point $\underline{P o g}$ to the line $\underline{\mathrm{Se}-\mathrm{N}}$;

SND (angle SND) - formed by lines $\underline{\mathrm{S}-\mathrm{N}}$ and $\underline{\mathrm{N}-\mathrm{D}}$ (indicates the anterior-posterior location of the symphysis (D - the center of the symphysis ossification) of the lower jaw to the base of the skull);

WITS (indicator Wits) - distance between constructive points $\underline{A O C l P}$ and BOclP - projections of the corresponding points $\underline{A}$ and $\underline{B}$ on the line apOcP-ppOcP (OcPSt, closing plane by Steiner), indicates a linear interjaw ratio in the anterior-posterior direction (if the projection of point $\underline{A}$ lies ahead of the projection of point $\underline{B}$ then the indicator takes a positive value; if the projection of point $\underline{A}$ lies behind the projection of point $\underline{B}$ then the indicator takes a negative value).

\section{Discussion}

One of the important indicators of the quality of orthodontic treatment is the stability of the results. Unfortunately, to date, the search for its solution is still ongoing, as relapses of tooth-jaw disease in one degree or another occur according to M.M. Khalil', E.V. Filimonova and M.V. Vologina data in $20 \%$ of cases [17]. Investigation of A. Koniarova et al. [18] indicate that the number of stable cases is only $16 \%$ higher than the number of relapses with which the statistically proven connections of some indices of the incisors positions.

Ethnic [19, 22], sexual and age [21] features of the incisors positions point to the need for the development of techniques that allow to determine their individual characteristics, since commonly accepted standards recommended for optimal positioning of incisors can only be used as indicative [3].

With the help of the step regression method, for Ukrainian young men and women with orthognathic bite, taking into account peculiarities of teleroentgenographic indices, developed reliable models (with a determination coefficient greater than 0.50 ) of individual teleroentgenographic characteristics of the position of the lower medial incisors. It was found that in young men from 7 possible models, 5 were constructed with determination coefficient $R^{2}$ from 0.694 to 0.849 , and in young women - all 7 possible models with determination coefficient $R^{2}$ from 0.595 to 0.794 .

In the analysis of constructed models with a determination coefficient of greater than 0.50 , it was found that in young men with orthognathic bite most often the regression equations included - an angle ANB, parameters of which indicate the angular interjaw ratio in the anterior-posterior direction and the vertical facial index GL_SN_S, whose parameters are determined by vertical correlations in the face profile (by $11.5 \%$ ); lower face height ANS_ME, face angle NBA_PTGN, whose parameters determine the direction of development of the mandible and the distance S_E, or the length of the back part of the skull base by Steiner (by $7.7 \%$ ). In young women with orthognathic bite most often the models included - the 
angle N_POG (16.7\%); the Wits indicator, whose parameters are determined by the linear interjaw ratio in the anterior-posterior direction (13.9\%); inclination angle $\mathbf{I}$, whose parameters determine the angle of inclination of the upper jaw to the nasal perpendicular $(8.3 \%)$; the $\mathbf{H}$ angle, whose parameters determine the angle of the Frankfurt plane to the base of skull, the maxillo-mandibular angle $\mathbf{M M}$, whose parameters determine the angle at which the upper jaw is located in relation to the lower jaw in the sagittal plane, as well as the angle of the face axis NBA_PTGN, whose parameters determine the direction development of the mandible (by $5.6 \%$ ).

The models developed by us allow to develop a computer program that can automatically calculate the individual teleroentgenographic characteristics of the position of the

\section{References}

[1] Alabdullah, M. M., Saltaji, H., Abou-Hamed, H., \& Youssef, M. (2014). The relationship between molar bite force and incisor inclination: a prospective cross-sectional study. Int. Orthod., 12(4), 494-504. doi: 10.1016/j.ortho.2014.10.001

[2] Ciavarella, D., Tepedino, M., Gallo, C., Montaruli, G., Zhurakivska, K., Coppola, L., ... Lo Russo, L. (2017). Postorthodontic position of lower incisors and gingival recession: $A$ retrospective study. J. Clin. Exp. Dent., 12(9), 1425-1430. doi: http://dx.doi.org/10.4317/jced.54261

[3] Dallel, I., Khemiri, M., Fathallah, S., Ben Rejeb, S., Tobji, S., \& Ben Amor, A. (2015). Incisor repositioning: a new approach in orthodontics. Orthod. Fr., 86(4), 327-338. doi: 10.1051/ orthodfr/2015031

[4] Dmitriev, M. O. (2016). Definition of normative cephalometric parameters by Steiner method for Ukrainian young men and women. World of Medicine and Biology, 3(57), 28-32.

[5] Dmitriev, M. O. (2017). Identification of normative cephalometric parameters based on $\mathrm{G}$. Schmuth method for young male and female Ukrainians. Reports of Morphology, 23(2), 288-292.

[6] Dmitriev, M. O. (2018). Determination of standard cephalometric parameters using the Downs method for Ukrainian adolescents. Reports of Morphology, 24(2), 22-26. doi: 10.31393/morphology-journal-2018-24(2)-03

[7] Dmitriev, M. O., Chugu, T. V., Gerasymchuk, V. V., \& Cherkasova, O. V. (2017). Determination of craniometric and gnatometric indicators by A. M. Schvartz metod for Ukrainian boys and girls. Biomedical and Biosocial Anthropology, 29, 53-58.

[8] Downs, W. B. (1956). Analysis of the dentofacial profile. Angle Orthodontist, 26, 191-212.

[9] Duncan, L. O., Piedade, L., Lekic, M., Cunha, R. S., \& Wiltshire, W. A. (2016). Changes in mandibular incisor position and arch form resulting from Invisalign correction of the crowded dentition treated nonextraction. The Angle Orthodontist, 86(4), 577-583. doi: https://doi.org/10.2319/042415-280.1

[10] Feng, F., Liu, Y., Chi, J., Wang, Y., Xing, B., Wang, Y., \& Liu, W. (2018). Effects of anterior tooth crown inclination on occlusal relationship-A study in three-dimensional reconstruction. Arch. Oral. Biol., 94, 48-53. doi: 10.1016/j.archoralbio.2018.06.015

[11] Garlock, D. T., Buschang, P. H., Araujo, E. A., Behrents, R. G., \& Kim, K. B. (2016). Evaluation of marginal alveolar bone in the anterior mandible with pretreatment and posttreatment computed tomography in nonextraction patients. American Journal of Orthodontics and Dentofacial Orthopedics, 149(2), 192-201. doi: 10.1016/j.ajodo.2015.07.034 lower medial incisors, which, in turn, will help orthodontists achieve the maximum physiological and aesthetic results.

\section{Conclusions}

In young men with orthognathic bite of 7 possible models, 5 were constructed with a determination coefficient from 0.694 to 0.849 , and in young women - all 7 models with a determination coefficient from 0.595 to 0.794 . In young men, the most commonly included models were the angle ANB, the vertical vertical index GL_SN_S (by $11.5 \%$ ); lower face height ANS_ME, face angle NBA_PTGN and distance S_E (by 7.7\%); in young women - the angle N_POG (16.7\%); Wits indicator (13.9\%); inclination angle I (8.3\%); $\mathbf{H}$-angle, maxillo-mandibular angle $\mathbf{M M}$ and angle of facial axis NBA_PTGN (by 5.6\%).

[12] Gunas, I. V., Dmitriev, M. O., Tikholaz, V. O., ShinkarukDykovytska, M. M., Pastukhova, V. A., Melnik, M. P., \& Rudiy, Yu. I. (2018). Determination of normal cephalometric parameters by J. McNamara method for Ukrainian boys and girls. World of Medicine and Biology, 1(63), 19-22. doi: 10.26724/2079-8334-2018-1-63-19-22

[13] Gunas, I. V., Dmitriev, M. O., Prokopenko, S. V., ShinkarukDykovytska, M. M., \& Yeroshenko, G. A. (2017). Determination regulatory cephalometric options by the method of Tweed International Foundation for Ukrainian boys and girls. World of Medicine and Biology, 4(62), 27-31. doi: 10.26724/2079-83342017-4-62-27-31

[14] Hernandez-Sayago, E., Espinar-Escalona, E., Barrera-Mora, J. M., Ruiz-Navarro, M. B., Llamas-Carreras, J. M., \& SolanoReina, E. (2013). Lower incisor position in different malocclusions and facial patterns. Med. Oral. Patol. Oral. Cir. Bucal., 1, 18(2), 343-350. PMID: 23229262

[15] Holdaway, R. A. (1984). A soft-tissue cephalometric analysis and its use in orthodontic treatment planning. Part II. Am. J. Orthod., 85, 279-293. doi: https://doi.org/10.1016/00029416(84)90185-4

[16] Huang, Y. P., \& Li, W. R. (2015). Correlation between objective and subjective evaluation of profile in bimaxillary protrusion patients after orthodontic treatment. Angle Orthod., 85(4), 690-6988. doi: 10.2319/070714-476.1

[17] Khalil', M. M., Filimonova, E. V., Vologina, M. V. (2008). The results of the study of the effectiveness of orthodontic treatment in the retention period. Abstracts are presented in the collection of scientific works of Volgograd State Medical University "Actual issues of experimental, clinical and preventive dentists". Collection of scientific papers of Volgograd State Medical University, 65(1), 346.

[18] Koniarova, A., Sedlata Juraskova, E., Spidlen, M., \& Statelova, D. (2017). The influence of orthodontic non-extraction treatment on the change in the inclination and position of incisors in the Europoid race. Bratisl. Lek. Listy, 118(11), 662-668. doi: 10.4149/BLL_2017_126

[19] Kumari, L., \& Das, A. (2017). Determination of Tweed's cephalometric norms in Bengali population. Eur. J. Dent., 11(3), 305-310. doi: 10.4103/ejd.ejd_274_16

[20] Kumari, N., Fida, M., \& Shaikh, A. (2016). Exploration of variations in positions of upper and Lower incisors, overjet, overbite, and irregularity Index in orthodontic patients with dissimilar depths of Curve of spee. J. Ayub. Med. Coll. 
Abbottabad, 28(4), 766-772.

[21] Linjawi, AI. (2016). Age- and gender-related incisor changes in different vertical craniofacial relationships. J. Orthod. Sci., 5(4), 132-137. doi: 10.4103/2278-0203.192116

[22] Lombardo, L., Perri, A., Arreghini, A., Latini, M., \& Siciliani, G. (2015). Three-dimensional assessment of teeth first-, secondand third-order position in Caucasian and African subjects with ideal occlusion. Prog. Orthod., 16, 11. doi: 10.1186/s40510015-0086-9

[23] Manea, I., Abascal-Pineda, I., Solano-Mendoza, B., SolanoReina, A., \& Solano-Reina, J. E. (2017). Facial growth pattern: Association between lower incisor position and symphyseal morphology. Journal of the World Federation of Orthodontists, 6(4), 147-151. doi: https://doi.org/10.1016/j.ejwf.2017.09.001

[24] McNamara, J. A. Jr. (1984). A method of cephalometric evaluation. Am. J. Orthod., 86(6), 449-469. PMID: 6594933

[25] MoraHurtado, R., VeraSerna, M. E., \& Uribe-Querol, E. (2016). Lower incisor inclination in relation to facial biotype in skeletal Class I patients. Inclinacion del incisivo inferior respecto al biotipo facial en pacientes clase l esqueletal. Revista Mexicana de Ortodoncia, 4(3), 157-162. doi: https://doi.org/10.1016/ j.rmo.2016.10.031

[26] Schmuth, G. P. F. (1971). Methodische Schwierigkeiten bei der Anwendung der Röntgenkephalometrie in der Kieferorthopadie. Fortschritte der Kieferorthopadie, 32(2), 317-325.

[27] Schwarz, A. M. (1960). Röntgenostatics; practical evaluation of the tele-X-ray-photo. Publisher: Brooklyn, N.Y.: Leo L. Bruder.

[28] Steiner, C. C. (1959). Cephalometrics in clinical practice. Angle Orthod., 29, 8-29.

[29] Tepedino, M., Franchi, L., Fabbro, O., \& Chimenti, C. (2018). Post-orthodontic lower incisor inclination and gingival recession-a systematic review. Prog. Orthod., 19(1), 17. doi: 10.1186/s40510-018-0212-6

[30] Tweed, C. H. (1954). The Frankfort-Mandibular Incisor Angle (FMIA) in Orthodontic Diagnosis, Treatment Planning and Prognosis. Angle Orthod., 3, 121-169.

\section{ВИЗНАЧЕННЯ ІНДИВІДУАЛЬНИХ ТЕЛЕРЕНТГЕНОГРАФІЧНИХ ХАРАКТЕРИСТИК ПОЛОЖЕННЯ НИЖНІХ ПРИСЕРЕДНІХ РІЗЦІВ У УКРАЇНСЬКИХ ЮНАКІВ I ДІВЧАТ IЗ ОРТОГНАТИЧНИМ ПРИКУСОМ}

Дмітрісв М.О., Гунас І.В., Дзевульська І.В., Глушак А.А.

Етнічні, статеві та вікові особливості положення різців вказують на необхідність розробки методик, що дозволяють визначити їх індивідуальні характеристики, оскільки загально прийняті стандарти, рекомендовані для оптимального позиціонування різців, можуть бути використані лише як орієнтовні. Мета дослідження - шляхом вивчення телерентгенографрічних показників і проведення прямого покрокового регресійного аналізу в юнаків $і$ дівчат України з ортогнатичним прикусом розробити та провести аналіз математичних моделей індивідуальних характеристик положення нижніх присередніх різців. За допомогою пристрою Veraviewepocs 3D, Моріта (Японія) у 38 юнаків (віком від 17 до 21 року) та 55 дівчат (віком від 16 до 20 років) з оклюзією, наближеною до ортогнатичного прикусу та збалансованими обличчями, були отримані бокові телерентгенограми. Цефралометричний аналіз проводили за допомогою програмного забезпечення

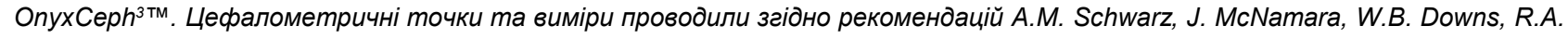
Holdway, P.F. Schmuth, C.C. Steiner ma C.H. Tweed. Зәідно вищенаведених методик, в ліцензійному пакеті "Statistica 6,0" з використанням прямого покрокового регресійного аналізу проведено моделювання телерентгенографічних характеристик положення нижніх присередніх різців (відстань 1I_NB, відстань 1I_APog, кym 1I_DOP, куm IMPA, кym Mand1_NB, кym FMIA ma куm Mand1_Melm). В юнаків із ортогнатичним прикусом із 7 можливих моделей телерентгенографрічних характеристик положення нижніх присередніх різців побудовано 5 з коефіцієнтом детермінації $R^{2}$ від 0,694 до 0,849 , а у дівчат - усі 7 можливих моделей з коефіцієнтом детермінації $R^{2}$ від 0,595 до 0,794. В юнаків найбільш часто до регресійних рівнянь входили - кут ANB та лицевий вертикальний індекс GL_SN_S (по 11,5\%); нижня висота обличчя ANS_ME, кут лицевої вісі NBA_PTGN ma відстань S_E (по 7,7\%). У дівчат найбільш часто до моделей входили - кут N_POG (16,7\%); показник Wits $(13, \overline{9} \%) ;$ інклінаційний кут I (8,3\%); Н-куm, верхньощелепно-нижньощелепний кут MM та кут лицевої вісі NBA_PTGN (по 5,6\%). Таким чином, за допомогою методу покрокової регресії з включенням, в українців юнацького віку на основі особливостей телерентгенографічних показників розроблені та проведений аналіз достовірних моделей індивідуальних телерентгенографрічних характеристик положення нижніх присередніх різців.

Ключові слова: положення нижніх присередніх різців, телерентгенографія, регресійний аналіз, ортогнатичний прикус, юнаки, дівчата.

\section{ОПРЕДЕЛЕНИЕ ИНДИВИДУАЛЬНЫХ ТЕЛЕРЕНТГЕНОГРАФИЧЕСКИХ ХАРАКТЕРИСТИК ПОЛОЖЕНИЯ НИЖНИХ ЦЕНТРАЛЬНЫХ РЕЗЦОВ У УКРАИНСКИХ ЮНОШЕЙ И ДЕВУШЕК С ОРТОГНАТИЧЕСКИМ ПРИКУСОМ \\ Дмитриев Н.А., Гунас И.В., Дзевульская И.В., Глушак А.А.}

Этнические, половые и возрастные особенности положения резцов указывают на необходимость разработки методик, позволяющих определить их индивидуальные характеристики, поскольку общепринятые стандарты, рекомендованные для оптимального позиционирования резцов, могут быть использованы только как ориентировочные. Цель исследования - путем изучения телерентгенографических показателей и проведения прямого пошагового регрессионного анализа у юношей и девушек Украины с ортогнатическим прикусом разработать и провести анализ математических моделей индивидуальных характеристик положения нижних центральных резцов. С помощью устройства Veraviewepocs $3 D$, Mopuта (Япония) у 38 юношей (в возрасте от 17 до 21 года) и 55 девушек (в возрасте от 16 до 20 лет) с окклюзией, приближенной к ортогнатическому прикусу и сбалансированными лицами, были получены боковые телерентгенограммы.

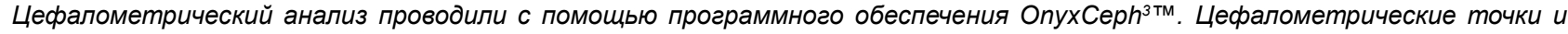
измерения проводили согласно рекомендациям A.M. Schwarz, J. McNamara, W.B. Downs, R.A. Holdway, P.F. Schmuth, C.C. Steiner u C.H. Tweed. Согласно вышеприведенных методик, в лицензионном пакете "Statistica 6.0" с использованием прямого пошагового регрессионного анализа проведено моделирование телерентгенографических характеристик положения нижних центральных резцов (расстояние 1I_NB, расстояние 1I_APog, угол 1I_DOP, угол IMPA, угол Мапd1_NB, угол FMIA и угол Mand1_Melm). У юношей с ортогнатическим прикусом из 7 возможных моделей телерентгенографрических характеристик 
положения нижних центральных резцов построено 5 с коэфффициентом детерминации $R^{2}$ om 0,694 до 0,849, а у девушек - все 7 возможных моделей с коэффрициентом детерминации $R^{2}$ om 0,595 до 0,794. У юношей наиболее часто в регрессионные уравнения входили - угол ANB и лицевой вертикальный индекс GL_SN_S (по 11,5\%); нижняя высота лица ANS_ME, угол лицевой оси NBA_PTGN и расстояние S_E (по 7,7\%). У девушек наиболее часто в модели входили - угол $N \_P O G(16,7 \%) ;$ показатель Wits (13,9\%); инклинационный угол I (8,3\%); Н-угол, верхнечелюстной-нижнечелюстной угол ММ и угол лицевой оси NBA_PTGN (по 5,6\%). Таким образом, с помощью метода пошаговой регрессии с включением, у украинцев юношеского возраста на основе особенностей телерентгенографических показателей разработаны и проведен анализ достоверных моделей индивидуальных телерентгенографических характеристик положения нижних центральных резцов.

Ключевые слова: положение нижних центральных резцов, телерентгенография, регрессионный анализ, ортогнатический прикус, юноши, девушки. 